AGRICA: Journal of Sustainable Dryland Agriculture, 12 (2): 111-125 (2019)

ISSN-Online : 2715-4955; ISSN-Cetak: 2715-6613

DOI: https://doi.org/10.37478/agr.v12i2.305

\title{
SIKAP DAN PERILAKU PETANI DESA PEMO SEBAGAI DESA WISATA NASIONAL DALAM USAHA WISATAAGRO DI KAWASAN TAMAN NASIONAL KELIMUTU ENDE- FLORES- NTT
}

\author{
Imaculata Fatima \\ Dosen Fakultas Pertanian Universitas Flores \\ E-mail:imapampe@gmail.com/imaculataf@yahoo.com \\ HP: $081238487238 / 085237958685$
}

\begin{abstract}
Attitude and behavior of pemo village farmers as national tourism village in tourismrous business in Kelimutu Ende-Flores-NTT National Park Area. The Kelimutu area has a famous panoramic beauty and is one of the wonders of the world. Various efforts have been made by the Kelimutu National Park Office to empower local communities through agro-tourism activities. Initially, the activity went well, but after two years, the effort stalled due to human resource constraints of agro-tourism farmers. This study aims to determine The attitudes and behavior of Pemo village farmers on agro-tourism, The ability of Pemo village farmers to run agro-tourism businesses, Impact for Pemo village farmers on agro-tourism businesses, The wishes of Pemo village farmers related to agro-tourism businesses, BTNK's readiness and ability to run agro-tourism businesses; and Models developed. The research method used is a descriptive method with a population of Pemo village farmers and 50 samples. Data collection techniques by questionnaire, observation, interview, and PRA. Data analysis with qualitative and quantitative analysis using correlation coefficients and simultaneous accuracy test or F test and partial t-test. In conclusion (1) Pemo residents have the attitude and behavior to agree to develop agro-tourism; (2) farmers are not able to continue the development of agrotourism because of human resource constraints; (3) Impacts which have been received by farmers are quite good economic and financial impacts; (4) Farmers want to continue to be facilitated and need assistance, facilities and infrastructure assistance for the smooth agro-tourism business, (5) BTNK is unable to meet farmers' desires due to cost constraints, (6) the models offered are re-program and re-structuring primary agro-farmer institutions.
\end{abstract}

Keywords: Attitudes, behavior, agro-tourism

\section{PENDAHULUAN}

Telah diketahui bahwa danau Kelimutu dengan tiga warna yang sesaat selalu berubah-ubah adalah keajaiban alam yang pantas dan patut dibanggakan oleh masyarakat bangsa Indonesia umumnya dan masyarakat Kabupaten Ende khususnya. Dengan keajaibannya menjadikan danau Kelimutu ini menjadi salah satu tempat tujuan wisata yang dari hari ke hari dalam pengamatan empirik ramai dikunjungi wisatawan mancanegara dan domestik, sehingga konon merupakan icon pariwisata bagi Kabupaten Ende yang berdampak pada adanya peningkatan pendapatan 
masyarakat di sekitarnya terutama sektor jasa, yang bermuara pada peningkatan pendapatan asli daerah Kabupaten Ende serta penambahan devisa negara Indonesia.

Namun, bila dikaji secara mendalam dan komprehensif, manfaat untuk peningkatan pendapatan masyarakat yang diperoleh dari keajaiban danau Kelimutu ini, bukan saja terbatas dari sektor jasa melainkan juga sektor pertanian melalui usahausaha pertanian dengan memanfaatkan lahan yang ada di kawasan itu sehingga dapat bermanfaat baik bagi petani itu sendiri, pemerintah, maupun wisatawan. Terkait dengan itu, pemerintah Kabupaten Ende bersama pemerintah Pusat, c.q Balai Taman Nasional Kelimutu (BTNK), secara terpadu telah meningkatkan pengelolaan kawasan danau Kelimutu sebagai pariwisata alamiahserta telah membangun pariwisata-pariwisata artifisial (buatan) melalui usaha wisata agro (agroecotourism) di kawasan Taman Nasional Kelimutu (TNK).

Wisata agro yang telah dilakukan oleh BTNK Kabupaten Ende dititikberatkan pada usaha tanaman hortikultura, dengan memberikan bibit kentang, wortel, sawi, dan bawang daun, juga tanaman umur panjang berupa pohon mahoni dan gaharu, serta cengkeh kepada petani yang menghuni di 23 desa di sekitar kawasan Kelimutu untuk ditanam pada lahan-lahan yang mereka miliki. Selain itu, juga disiapkan air dan tenaga-tenaga teknis baik yang bertugas sebagai pendamping maupun bertugas memberikan penyuluhan-penyuluhan dan pelatihan-pelatihan untuk peningkatan sumber daya manusia (SDM) petani di kawasan agrowisata itu. Dengan adanya wisata agro ini, di satu sisi dapat mendukung pariwisata Kelimutu \& pada sisi lain dapat menambah daftar objek-objek pariwisata di Kabupaten Ende. Dari 23 desa tersebut, desa Pemo oleh Kementrian Pariwisata dan Kebudayaan Republik Indonesia, c.q. Dirjen Pariwisata dan Kebudayaan ditetapkan sebagai Desa Wisata Nasional (national rural tourism). Diasumsikan bahwa pertimbangan pokok desa ini ditetapkan sebagai desa wisata nasional (DWN) adalah (1) terletak tidak jauh dari danau Kelimutu; (2) lalu lintas lancar; dan (3) sering menjadi tempat kegiatan-kegiatan yang berhubungan dengan taman nasional Kelimutu. Pelbagai konsekuensi dengan ditetapkan desa Pemo sebagai DWN, di antaranya adalah kesanggupan (ability) masyarakatnya untuk menjalankan usaha wisataagro dengan sasaran pokok pada usaha tanaman hortikultura dan tanaman umur panjang, sebagaimana telah disebutkan di atas. Sepintas diamanti secara empirik terhadap usaha-usaha wisataagro yang telah dilakukan oleh BTNK Kabupaten Ende, khusus bagi masyarakat desa Pemo, terkesan mubazir sehingga menjadi permasalahan yang perlu dipecahkan secara serius oleh pemerintah khususnya pihak BTNK Kabupaten Ende.

Agrowisata didefinisikan sebagai sebuah rangkaian kegiatan wisata denganmemanfaatkan potensi pertanian sebagai objek wisata, baik berupa panoramaalam kawasan pertaniannya maupun keunikandan keanekaragaman 
aktivitas produksi dan teknologi pertaniannya serta budaya masyarakat pertaniannya(Palit, Talumingan, \& Rumagit, 2017). Sedangkan definisi agrowisata dalam Surat keputusan Bersama (SKB) Menteri Pertanian dan Menteri Pariwisata, Pos dan Telekomunikasi Nomor 204/Kpts/HK/050/4/1989 dan Nomor KM.47/PW.DOW/MPPT/89 tentang Koordinasi Pengembangan Wisata Agro yakni sebagai suatu bentuk kegiatan pariwisata yang memanfaatkan usaha agro sebagai obyek wisata dan bertujuan untuk memperluas pengetahuan, perjalanan, rekreasi dan hubungan usaha di bidang pertanian.Usaha agro didefinisikan sebagai usaha pertanian dalam arti luas mencakup pertanian lahan kering, sawah, palawija, perkebunan, peternakan, kehutanan, pekarangan, tegalan, lading (Mayasari \& Ramdhan, 2013). Berbagai proses kegiatan mulai dari budidaya agro, pra panen, pasca panen, berupa pengolahan hasil hingga proses pemasaran dapat dijadikan obyek agrowisata. Agrowisata telah berhasil mempromosikan pembangunan pedesaan dan melindungi lingkungan karena agrowisata cenderung mengembangkan teknik yang lebih berkelanjutan yang berdampak positif terhadap keanekaragaman hayati, lanskap dan sumber daya alam(Mastronardi et al., 2015).Berdasarkan latar belakang yang telah dipaparkan, penelitian tentang sikap dan perilaku petani Desa Pemo dalam pengembangan agrowisata perlu dilakukan.

\section{METODE PENELITIAN}

Metode penelitian yang dipakai adalah metode deskriptifdengan pendekatan kualitatif dan kuantitatif secara terpadu.Penelitian ini tidakselalu membutuhkan hipotesis (Kusmaryadi dan Sugiyarto, 2010). Lebih lanjutmenurut Arikunto (2010) menekankan bahwa, penelitian deskriptif tidakdimaksudkan untuk menguji hipotesis tertentu, tetapi hanya menggambarkan "apaadanya" tentang variabel, gejala atau keadaan serta tidak memerlukan administrasiatau pengontrolan terhadap sesuatu perlakuan.

\section{Identifikasi Variabel}

Sesuai dengan permasalahan yang telah dikemukakan, maka penelitian ini terdiri atas 2 (dua) variabel yakni variabel bebas adalah sikap dan variabel terikat adalah perilaku dalam mengembangkan wisata agro.

\section{Polulasi dan Sampel}

Populasi yang diteliti adalah semua petani di Desa Pemo yang terdiri atas 143 kepala keluarga. Teknik pengambilan sampel (teknik sampling) menurut Nawawi (2011), adalah cara untuk menentukan sampel yang jumlahnya sesuai dengan ukuransampel yang akan dijadikan sumber data sebenarnya, dengan memperhatikan sifat-sifat dan penyebaran populasi agar diperoleh sampel yang benar-benar mewakili populasi. Pengambilan sampel dilakukan dengan cara random sampling, sebanyak 50 orang yangberasal dari 143 petani masyarakat desa Pemo. Sampel ini kemudian dibagi ke dalam dua kelompok berdasarkan aktivitasnya secara langsung di kawasan wisata agro sebanyak 13 orang dari 24 orang dan di luar kawasan wisata agro sebanyak 31orang dari 119 petani dan 6 orang petani mosalaki dari 11 orang. 
Mantra, (1985) dalam Singarimbun dan Affandi (2012) menyatakan besarnya sampel tidak boleh kurang/minimum 5\%.

\section{Metode Pengumpulan Data}

Untuk mendapatkan outputyang diinginkan terutama model pemberdayaan petani, digunakan metode enkeltik, yakni paduan antara metode PRA (participatory rural appraisal) denganpengamatan terlibat (partisipation observation) dan tidak terlibat (nonpartisipation observation), di samping survey secara komprehensif yang didukung teknik kuesioner tertutup dan terbuka serta wawancara mendalam terstruktur dan tidak terstruktur.

\section{Analisa Data}

Teknik pengolahan data yang akan digunakan adalah dengan menggunakanteknik induktif, yaitu dari fakta dan peristiwa yang diketahui secara konkrit,kemudian digeneralisasikan ke dalam suatu kesimpulan yang bersifat umum yangdidasarkan atas fakta-fakta yang empiris tentang lokasi penelitian. Moloeng(2010) mengatakan, bahwa dengan menggunakan analisis secara induktif, berartipencarian data bukan dimaksudkan untuk membuktikan hipotesis yang telahdirumuskan sebelum penelitian dilakukan. Analisis data dilakukan dengan metodedeskriptif kualitatif dan kuantitatif.

\section{a. Analisis deskriptif kualitatif}

Analisis ini dipergunakan untuk mengetahui sikap dan perilaku petani di kawasan wisata agro dan di luar kawasan wisata agroDesa Pemo. Analisisnyaberdasarkan klasifikasi responden yang terbagi ke dalam 5 kelompok yakni :Kelompok A: Responden secara keseluruhan berjumlah : 50 orang; Kelompok B : Responden di kawasan agro- 8 berjumlah: 8 orang; Kelompok $\mathrm{C}$ : Responden di kawasan agro-24 berjumlah : 5 orang; Kelompok D. Responden kelompok mosalaki berjumlah 6 orang; Kelompok E : Responden kelompok petani di luar agro : 31 orang. Data yang dipakai diperoleh melalui wawancara, pengamatan langsung, dan PRA.Untuk melengkapi deskripsi secara kualitatif, perlu dilakukan analisis secara kuantitatif.

\section{b. Analisis kuantitatif}

Analisis data dengan menggunakan statistik deskriptif. Tujuannya adalahuntuk mengetahui secaradeskriptif sikap dan perilaku masyarakat terhadap pengembangan wisata agro di desa Pemo,melalui skalalikert. MenurutKusmaryadi dan Sugiarto (2012), skala Likert ini merupakan alat untukmengukur sikap dan perilaku dari keadaan yang sangat positif ke jenjang sangat negatif,untuk menunjukkan sejauh manakah tingkat persetujuan atau ketidaksetujuanterhadap pernyataan yang diajukan oleh peneliti. Skala Likert ini disebut jugasebagai Summated Rating Methodyang akanmenentukan skor pada pengukuran skala Linkertdengan pemberianskor tertinggi dan terendah dari setiap jawaban pertanyaan yangdiajukan kepada responden. Jawabanpertanyaan tertinggi diberi nila 5, sedangkan untuk jawaban terendah adalah1.Jawaban diantara kedua skala tersebut disesuaikan dengan jumlah jawabanyang ada, untuk pertanyaan sangat setuju diberi nilai 5, setuju diberi nilai 4,tidak pasiidiberi nilai 3, tidak setuju diberi nilai 2 , dan 1 sangat tidak setuju.Untuk memperoleh peringkat sikap dan perilaku petani di desa Pemo, diajukan 15 pertanyaan.Nilai positif dan negatif dapat dilihat dari rata-rata jawaban seluruh 
responden untuk setiap kategori pada setiap item pertanyaan maupun untuk seluruh pertanyaan.Nilai 4-5 dinyatakan positif, nilai 3 tidak pasti, dan nilai 1-2 dinyatakan negatif.

Selanjutnya untuk mengetahui hubungan antara kedua variable, dapat dilakukan dengan analisis korelasi.Korelasi (correlation) adalah salah satu teknik statistik yang digunakan untuk mencari hubungan antara dua variabel atau lebih yang sifatnya kuantitatif.Dalam analisis korelasi akan terdapat arah hubungan antara dua variabel, yakni: (1) Direct correlation (Positive correlation). Perubahan pada salah satu variabel diikuti perubahan variabel yang lain secara teratur dengan arah / gerakan yang sama; (2) Inverse correlation (Negative correlation). Perubahan pada salah satu variabel diikuti perubahan variabel yang lain secara teratur dengan arah / gerakan yang berlawanan. (Djarwanto, 2010:321-322)

Koefisien korelasi yang dinyatakan dengan bilangan, bergerak antara 0 sampai dengan +1 atau antara 0 sampai dengan -1.Apabila koefisien korelasi ( $r$ ) mendekati +1 atau -1 berarti terdapat hubungan yang kuat, sebaliknya apabila mendekati 0 berarti terdapat hubungan yang lemah atau tidak ada hubungan. Apabila $r=+1$ atau -1 berarti terdapat hubungan positif sempurna atau hubungan negatif sempurna atau dapat ditulis sebagai berikut: $-1 \leq \mathrm{r} \leq+1$. (Djarwanto, 2010:324). Disamping koefisien korelasi perlu memperhatikan juga uji statistik yang lainnya yakni uji ketepatan (godness of fit) yakni pengujian secara simultan, parsial dan koefisein determinasi $\left(\mathrm{R}^{2}\right)$.

Adapun uji ketepatan tersebut adalah sebagai berikut. (1) Uji Simultan (uji F); Untuk mengetahui pengaruh variabel bebas (sikap) secara keseluruhan terhadap variabel terikat (perilaku) akan digunakan uji $\mathrm{F}$. Selanjutnya nilai uji $\mathrm{F}$ ini dibandingkan dengan nilai $F_{\text {tabel }}$ pada alpha $(\alpha=5 \%)$. Apabila $\quad F_{\text {statistik }}>F_{\text {tabel }}$ maka variabel bebas yakni sikap secara keseluruhan berpengaruh signifikan terhadap variabel terikat yakni perilaku, tetapi apabila $\mathrm{F}_{\text {statistik }}<\mathrm{F}_{\text {tabel }}$ maka variabel bebas secara keseluruhan tidak berpengaruh signifikan terhadap variabel terikat; (2) Uji parsial (uji t). Pengujian secara parsial digunakan untuk melihat pengaruh masing-masing variabel bebas terhadap variabel terikat. Selanjutnya nilai uji $\mathrm{t}$ ini dibandingkan dengan nilai $t_{\text {tabel }}$ pada alpha $(\alpha=5 \%)$. Apabila $t_{\text {statistik }}>t_{\text {tabel }}$ maka variabel bebas secara individual berpengaruh signifikan terhadap variabel terikat, tetapi apabila $\mathrm{t}_{\text {statistik }}<\mathrm{t}_{\text {tabel }}$ maka variabel bebas secara individual tidak berpengaruh signifikan terhadap variabel terikat; (3) Koefisien deteminasi $\left(\mathrm{R}^{2}\right)$. Kontribusi dari variabel bebas terhadap variabel terikat dapat dilihat dari besarnya nilai $R^{2}$. Nilai $R^{2}$ tersebut berkisar dari 0 sampai dengan 1. $\left(0 \leq \mathrm{R}^{2} \leq 1\right)$. Apabila $\mathrm{R}^{2}=0$, berarti variabel bebas tidak mempunyai kontribusi terhadap variabel terikat. Tetapi apabila $\mathrm{R}^{2}=1$ berarti variabel bebas mempunyai kontribusi sempurna $(100 \%)$ terhadap variabel terikat. 
HASIL DAN PEMBAHASAN

Gambaran Umum Balai Taman Nasional Kelimutu

Taman

Nasional

Kelimutuditunjuk sebagai Kawasan

Taman Nasional berdasarkan Surat

Keputusan

Menteri

Kehutanan,SK.No.279/Kpts-II/92

dengan luas \pm 5.000 hektar. Kemudian

Tahun 1997 ditetapkan melalui SK.

Menteri Kehutanan melalui

SK.No.675/Kpts.-II/97 dengan luas

5.356,5 hektar dan garis batas total sepanjang 48.423,44 $\mathrm{m}$ yang terdiri dari 241 pal batas hutan kawasan yang membatasi badan Taman Nasional dengan 24 desa pada lima wilayah Kecamatan di Kabupaten Ende.

Hasil inventarisasi di Taman Nasional Kelimutu terdapat beraneka ragam hayati yang memiliki keunikan dan nilai estetika yang menarik dengan adanya danau tiga warna yang berada di puncak Gunung Kelimutu dengan ketinggian 1.690 meter dpl. Awal mulanya daerah ini ditemukan oleh Van Such Telen, warga negara Belanda pada 1915.Keindahannya dikenal luas setelah Y. Bouman melukiskan dalam tulisannya pada 1929. Secara ilmiah menurut ahli geologi, perubahan warna pada ketiga danau disebabkanoleh reaksi kimia yang muncul dari mineral-mineral di dasar danau yang mungkin terpicu oleh aktivitas gas vulkanik.

Menurut data Balai Taman Nasional Kelimutu, dari tahun 1915sampai dengan hari kamis, 27 Desember 2018, jam senja hari, sudah terjadi puluhan kali perubahan warna. Warna Danau Ata Polo mengalami 46 kali perubahan, Nua Muri Koo Fai 25 kali, dan Ata Mbupu telah 16 kali.Tahun 2018 tanggal 27 Desember perubahaan warna pada danau Ata Polo dari hijau toska menjadi hijau daun dan seminggu kemudian menjadi coklat tua. Sebelumnya perubahan warna danau terjadi pada bulan Januari - Maret, namun tahun 2018 terjadi lebih cepat yakni bulan Desember. Sejak 26 Februari 1992, kawasan Kelimutu telah ditetapkan menjadi Kawasan Konservasi Alam Nasional.

\section{Gambaran Sikap dan Perilaku Petani Desa Pemo dalam Pengembangan Wisata Agro di Taman Nasional Kelimutu}

Mengacu pada tujuan penelitian yang telah ditetapkan, dan berdasarkan hasil penelitian, ditemukan beberapa hal berikut.

1) Menemukan sikap dan perilaku petani desa Pemo atas usaha wisata agro

Secara garis besar petani di kawasan wisata agro memiliki sikap yang positif terhadap pengembangan kawasan wisata agro. Hasil analisis kuantitatif koefisien korelasi menunjukkan bahwa terdapat arah hubungan antara dua variabel, yakni:

\section{Sikap dan perilaku kelompok $A$}

Kelompok A mempunyai nilai koefisien korelasi sebesar 0,511, yang artinya dalam kelompok A hubungan antara sikap terhadap perilaku adalah kuat. Keadaan tersebut dijelaskan pula oleh nilai koefisien determinasi sebesar 0,261 atau $26,1 \%$, yang artinya kontribusi dari sikap terhadap perilaku sebesar $26,1 \%$ sedangkan sisanya sebesar $73,9 \%$ dijelaskan oleh variabel 
lain yang tidak diteliti. Secara parsial juga terlihat bahwa sikap berpengaruh signifikan terhadap perilaku.Hasil analisis data menunjukkan $t_{\text {statistik }}$ yang >

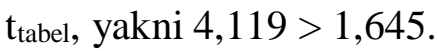

\section{Sikap dan perilaku kelompok kelompok B (kelompok Agro-8)}

Kelompok B nilai koefisien korelasinya adalah sebesar 0,149, yang artinya dalam kelompok $\mathrm{B}$, hubungan antara sikap terhadap perilaku adalah kuat. Meskipun kontribusi dari sikap terhadap perilaku sangat kecil sebagaimana yang terlihat pada nilai koefisien determinasi yang sebesar 0,022 atau 2,2\%, Berarti masih ada variabel lain yang mempunyai kontribusi (sebesar 97,8\%) terhadap perilaku. Secara parsial juga terlihat bahwa sikap tidak berpengaruh signifikan terhadap perilaku.Hal ini dapat dilihat dari $t_{\text {statistik }}$ yang $<t_{\text {tabel, }}$ yakni $0,370<1,645$.

Sikap dan perilaku kelompok $\mathrm{C}$ (Kelompok Agro-24)

Kelompok C nilai koefisien korelasinya sebesar 0,333, artinya hubungan antara sikap terhadap perilaku dalam kelompok $\mathrm{C}$ dinyatakan kuat. Meskipun kontribusi dari sikap terhadap perilaku sangat kecil sebagaimana yang terlihat pada nilai koefien determinasi yang sebesar 0,111 atau 11,1\%, Masih ada variabel lain yang mempunyai kontribusi (sebesar 88,9\%) terhadap perilaku. Secara parsial juga terlihat bahwa sikap tidak berpengaruh signifikan terhadap perilaku.Hasilnya dilihat dari $\mathrm{t}_{\text {statistik }}$ yang $<\mathrm{t}_{\text {tabel}}$, yakni $0,611<1,645$.

Sikap dan perilaku kelompok D (Kelompok Mosalaki)
Kelompok D nilai koefisien korelasinya sebesar 0,297, artinya sikap kelompok Dmempunyai hubungan yang kuatterhadap perilaku. Meskipun kontribusi dari sikap terhadap perilaku sangat kecil sebagaimana yang terlihat pada nilai koefisien determinasi sebesar 0,088 atau $8,8 \%$, Masih ada kontribusi variabel lain sebesar $91,2 \%$ terhadap perilaku. Secara parsial juga terlihat bahwa sikap tidak berpengaruh signifikan terhadap perilaku.Hal ini dapat dilihat dari $\mathrm{t}_{\text {statistik }}$ yang $<\mathrm{t}_{\text {tabel}}$, yakni $0,622<1,645$.

Sikap dan perilaku kelompok $\mathbf{E}$ (Kelompok petani di luar Agro)

Kelompok E mempunyai nilai koefisien korelasi sebesar 0,575, yang artinya dalam kelompok $\mathrm{E}$ tersebut hubungan antara sikap terhadap perilaku adalah kuat. Keadaan tersebut dijelaskan pula oleh nilai koefisien determinasi sebesar 0,330 atau $33,0 \%$, yang artinya kontribusi dari sikap terhdap perilaku adalah sebesar $33,0 \%$ sedangkan sisanya sebesar $67 \%$ dijelaskan oleh variabel lain yang tidak diteliti. Secara parsial, sikap berpengaruh signifikan terhadap perilaku.Hasilnya dilihat dari $t_{\text {statistik }}$ yang $>t_{\text {tabel}}$, yakni 3,783 > 1,645.

2) Menemukan Perilaku Petani Desa Pemo Atas Usaha Wisata Agro

Perilaku yang ditampilkan dari hasil penelitian bahwa petani di kawasan wisata agro telah melaksanakan pengembangan di kawasan wisata agro dan mereka menyatakan setuju untuk mengembangkan kawasan tersebut. Namun dalam pelaksanaannya ada beberapa kendala yang langsung dialami adalah sebagai berikut: 1) Masalah lahan 
yang tidak subur; 2) Masalah hama (babi hutan dan kera); 3) Masalah kurangnya tenaga kerja; 4) Masalah pasar produk pertanian yang tidak jelas; 5) Masalah kurangnya dukungan masyarakat petani desa pemo di luar kawasan agro; 6) Tidak adanya ketentuan tertulis yang jelas dan pasti antara pemerintah dan petani pengelola kawasan wisata agro.

3) Hubungan Sikap dan perilaku petani desa pemo

Setelah dianalisis dengan korelasi product moment dinyatakan 0,555 yang berkisar antara 0 - dinyatakan positip yang berarti berbanding lurus. Jadi sikap petani terhadap perilaku dalam pengembangan wisata agro sangat kuat. Maksudnya bahwa aspek sikap sangat kuat pengaruhnya terhadap pembentukan sikap petani di kawasan wisata agro untuk melaksanakan atau mengembangkan usaha wisata agro secara baik. Untuk mewujudkan semua itu haruslah memiliki sikap yang positif. Jika petani memiliki sikap positip maka sangat mudah untuk berperilaku positif.

4) Menemukan kesanggupan petani desa Pemo untuk menjalankan usaha wisata agro Berkembangnya usaha wisata agro di Kawasan Kelimutu tidak terlepas dari adanya dukungan masyarakat desa Pemo baik secara langsung maupun tidak langsung. Dukungan masyarakat dapat terjadi jika didalamnya telah ada pemahaman yang mendalam tentang apa, mengapa, siapa, dimana, kapan, dan bagaimana, wisata agro dikembangkan. Terbentuknya pemahaman tentang hal tersebut, sangat ditentukan oleh adanya upaya sosialisasi kepada berbagai pihak termasuk masyarakat desa pemo sebagai basisnya. Pertanyaan pentingnya pengembangan wisata agro bagi masyarakat pemo yang dijabarkan dengan pemahaman tersebut di atas, tampaknya belum familiar bagi masyarakat desa Pemo. Dari hasil dialog dengan masyarakat desa di kantor desa Pemo pada tanggal 28 Juni 2016 ditemukan bahwa masyarakat desa pemo tidak semuanya paham tentang pengembangan wisata agro. Pernyataan ini dapat dibuktikan dengan kegiatan sosialisasi yang telah dilakukan oleh BTNK hanya dilakukan beberapa kali dan menghadirkan perwakilan dari masyarakat desa terutama warga desa yang lahannya dijadikan tempat pengelolaan wisata agro.

Insisiatif pihak BTNK sangat luar biasa untuk pengembangan wisata agro di kawasan Kelimutu dengan tujuan pentingnya adalah untuk meningkatkan kesejahteraan bagi masyarakat di samping untuk membangkitkan semangat masyarakat terhadap konservasi lingkungan dan pelestarian budaya setempat. Langkah awal dilakukan adalah sosialisasi rencana tersebut kepada warga masyarakat yang terwakili oleh beberapa warga, BAPPEDA, BAPEDALDA, DISPERINDAG, Dinas Pariwisata, Dinas Kehutanan dan Perkebunan, tokoh masyarakat diantaranya. Sosialisasi I dilaksanakan di desa Saga dan sosialisasi keduabersama masyarakat desa Pemo di Kantor Kec. Kelimutu tanggal 14 Februari 2008.

Menghadapi pemahaman petani desa pemo yang samar-samar tentang 
pengembangan wisata agro, maka pertemuan yang dilaksanakan di desa Pemo pada tanggal 28 Juni 2016, diawali dengan penjelasan tentang keberadaan agrowisata dan manfaatnya bagi masyarakat pemo. Penjelasan tersebut ternyata membuahkan respon yang sangat positif dari peserta pertemuan dan salah satu peserta mewakili yang hadir pada saat itu menyatakan dengan lantang bahwa:

"Masyarakat pemo sangat mendukung pengembangan agrowisata di kawasan kelimutu desa Pemo. Kepasifan kami selama ini terjadi, karena kurang dilibatkan dalam pengelolaanya dan kami menganggap bahwa kawasan agrowisata merupakan tanggung jawab dari ke-24 petani yang mengelolanya dan BTNK. Namun setelah mendengar penjelasan dari peneliti dan Kades Pemo baru dipahami tentang pentingnya pengembangan agrowisata bagi kami”.

Hasil penelitian menunjukkan dukungan petani desa pemo terhadap pentingnya pengembangan agrowisata bagi mereka yaitu sebanyak $50 \%$ menyatakan sangat setuju dan $44 \%$ menyatakan setuju. Dan untuk petani yang mengelola kawasan wisata agro yang berjumlah 8 orang (KWA-8) menyatakan sikap sangat setuju $63 \%$ dan setuju 38\%. Berdasarkan tabel skor pernyataan sikap petani secara total, jumlah skor skala sikapnya adalah 197 dgn rata-rata $4,4, \&$ disimpulkan ke dalam sikap yg sama yaitu setuju. Berdasarkan data disimpulkan bahwa masyarakat petani desa Pemo menyatakan sanggup untuk melaksanakannya. Dari pernyataan yang dikemukakan bahwa kawasan wisata agro adalah tanggung jawab petani di kawasan tersebut, mengindikasikan bahwa masyarakat di luar kawasan merasa tidak terlalu penting dalam pengelolaan kawasan agro wisata. Pelibatan masyarakat secara keseluruhan sangat minim dan lebih fokus pada pemberdayaan pada petani yang berada di kawasan agrowisata. Hal ini dapat menimbulkan kecemburuan yang berdampak pada ketakpedulian masyarakat baik terhadap pemerintah setempat maupun pada lingkungannya serta program-programnya.

\section{5) Menemukan dampak bagi petani desa Pemo atas usaha wisata agro.}

Dampak yang ditimbulkan bagi petani desa Pemo atas usaha wisata agro lebih fokus pada petani di kawasan Agro (KWA-8). Dampak secara langsung diantaranya adanya manfaat keuntungan secara ekonomi. Manfaat ini mendorong petani untuk terus mengembangkan usaha terutama dari penjualan sayursayuran wortel dan daun bawang. Manfaat lain yang diperoleh adalah adanya peningkatan sumber daya manusia yang difasilitasi oleh pemerintah (BTNK) bersama lembaga pendidikan tinggi yakni Universitas Flores serta atas kemauan atau inisiatif sendiri dari petani untuk belajar. Hal ini dapat dilihat dari perwujudan sikap dalam perilaku yang ditampilkan pada jawaban item manfaat ekonomi dan SDM adalah sebagai berikut. Pernyataan perilaku tentang kemampuan sumber daya manusia yang perlu ditingkatkan dan membutuhkan bantuan pihak lain $90 \%$, menyatakan setuju untuk 
meningkatkan kemampuan sumber daya manusia dalam pengembangan agrowisata melalui pendidikan nonformal, informal, pendampingan, dan magang.

Sebesar $77 \%$ menyatakan setuju dan berani berperilaku positip karena sadar atas kekurangan dalam bertani dan petani telah belajar melalui pelatihan dan magang. Dengan senang hati dan terbuka mereka telah magang di Gunung Bromo. Walaupun sudah diberikan pelatihan dan mengikuti magang, para petani sebanyak 44 orang dan $87 \%$ menyatakan bahwa pendidikan dan pelatihan didapatkan belum cukup, oleh karena itu kami telah berusaha meningkatkannya, dengan belajar dari petani yang sudah berhasil dan minta pihak Universitas Flores dan BTNK untuk terus mendampingi. Sebesar 58\% menyatakan setuju bahwa pendidikan dan pelatihan yang telah mereka terima selama ini sesuai dengan kebutuhan petani dalam bidang pertanian.

Manfaat ekonomi yang diterima petani juga telah mendorong para petani untuk terus kreatif melanjutkan usaha pengembangan di kawasa wisata agro karena mereka telah mendapatkan keuntungan secara ekonomi dan finansial. Sebesar $58 \%$ menyatakan setuju bahwa aktivitas di kawasan agro wisata telah memberikan manfaat bagi para petani secara langsung.

6) Menemukan Keinginan Petani Desa Pemo Terkait Dengan Usaha Wisata Agro

Berdasarkan hasil penelitian pada petani desa pemo ditemukan hal-hal berikut. (1) Petani menginginkan adanya ketersediaan pupuk; (2) Masalah hama (babi hutan dan kera) agar menjadi tanggung jawab bersama seluruh masyarakat desa Pemo dan pemerintah; (3) Masalah kurangnya tenaga kerja agar bisa memberdayakan warga masyarakat desa pemo atau pihak lain yang bersedia untuk mengelola; (4) Masalah pasar produk pertanian agar disediakan; (5) Masalah kurangnya dukungan masyarakat petani desa pemo di luar kawasan agro, petani menginginkan agar petani di desa pemo dan seluruh pihak terkait dapat berpartisipasi secara jelas dan bertanggung jawab. Terbentuknya kelembagaan yang mencakup semua aspek yang diperlukan untuk kemajuan aktivitas di kawsan wisata agro; (6) Perlu adanya ketentuan tertulis yang jelas dan pasti antara pemerintah dan petani pengelola kawasan wisata agro; (7) Perlu tersedianya sarana dan prasana transportasi dan gudang yang khusus untuk produk pertanian di kawasan agro.wisata

\section{7) Model Pengembangan Agro Wisata di Kawasan Kelimutu}

1. Pembentukan kelembagaan usaha agro wisata yang didukung oleh semua pihak termasuk petani desa pemo di luar kawasan agro wisata.

Pengembangan agro wisata memerlukan dukungan semua pihakpemerintah, swasta terutama pengusaha agro,wisata lembaga yang terkaitseperti perjalanan wisata, perhotelan dan lainnya, perguruan tinggi sertamasyarakat.Pada dasarnya ada tigakomponen yang cukup menentukan, yaitu pemerintah, pengusaha/investor, dan pelaksana/ tenaga operasional. 
a. PemerintahKabupaten Endeberperan dalam upaya mengembangkan wisata agro di desa Pemo kawasan Kelimutu, ruang lingkupperanannya berkaitan dengan pembuatan penetapan dan pelaksanaan peraturan-peraturan. Masalah yang dihadapi di kawasan agro wisata kelimutu adalah lahan itu milik masyarakat yang status dan pengelolaannya belum jelas hak dan kewajibannya.Hal ini menimbulkan kebimbangan pada para pemilik lahan untuk terus melaksanakan pekerjaan di kawasan wisata agro.

Pemerintah juga diharapkan memberikan pembinaan dan penyuluhanuntuk mendorong pengembangan wisata agro. Pembinaan danpenyuluhan dapat dilakukan oleh instansi yang terkait denganwisataagro, seperti Dinas Pertanian, Dinas Pariwisata, Seni Budayadan Olah Raga, Dinas Pengelolaan Lingkungan Hidup Kabupaten Ende, Lembaga Pendidikan Tinggi, LSM juga kelompok petani sukses, serta memfasilitasi ketersediaan Saprotan dan alsintan serta dana sebagai stimulus bagi pelaksana atau tenaga operasional. Diperlukan fungsi pengawasan untuk mencegah terjadinya penyimpangan yang dilakukan oleh investor danpengelola wisataagro.

b. Pengusaha/investor, berperan di dalam penyediaan modal danpengelolaan atau manajemen. Apabila Pemerintah PEMDA Endeakanmengembangkan wisataagro dengan biaya sendiri, pengembangannyadapat melalui Perusahaan Daerah Aneka Usaha Kabupaten Ende.Apabila dalam pengembangan wisataagro akan melibatkan pengusahaatau investor, disarankan mengutamakan pengusaha pribumi yangmemiliki pengalaman dalam pengembangan wisataagro dari Kabupaten Ende, dengan kerjasama pemodalan atau hanya kontrak kerjapengelolaan, agar tidak sekedar coba-coba sehingga lebih efisien dan efektif.

c. Pelaksana operasional. Sebagai pelaksana operasional wisataagro berwawasan lingkungan membutuhkan sumberdaya manusia mulai dari pengelola sampai dengan peranserta masyarakat. Pelaksana berperan penting dalam keberhasilan pengembangan wisata agro. Kemampuan pengelola wisata agro dalam menetapkan target sasaran dan menyediakan, mengemas, menyajikan paket-paket wisata serta promosi yang terus menerus sesuai dengan potensi yang dimiliki sangat menentukan keberhasilan dalam mendatangkan wisatawan. Pemandu wisata merupakan salah satu sumberdaya manusia yang sangat penting. Kemampuan pemandu wisata yang memiliki pengetahuan ilmu dan keterampilan menjual produk wisata sangat menentukan. Pengetahuan pemandu wisata tidak hanya terbatas kepada produk dari obyek wisata yang dijual tetapi juga pengetahuan umum tentang produk wisata.

Hal ini sejalan dengan pendapat Bambang bahwa :'Untuk 
meningkatkan hasil pengelolaan suatu obyek wisata, tidaksekedar menciptakan obyek wisata dan melengkapi dengan atraksiatraksiwisata saja, namun peran pemandu wisata sangat besar,pengetahuan umum yang mereka miliki sangat dibutuhkan olehwisatawan, mereka inilah yang biasanya membawa wisatawan ketempat tujuan obyek wisata baru, banyak ditemui calon wisatawanyang hanya mengetahui tempat-tempat wisata yang sudah punyanama. Untuk mempromosikan tempat-tempat obyek wisata baru peranan pemandu wisata ini sangat besar, makanya pengelola obyek wisata harus pintar-pintar menjalin hubungan dengan pemandu wisata". Pengelolaan obyek wisataagro yang baik memerlukan tenaga terampil yang memiliki keahlian di bidangnya masing-masing, diantaranya : (1) Manajer; (2) Ahli budidaya tanaman; (3) Ahli ekonomi; (4) Ahli konstruksi dan desain; (5) Ahli lingkungan hidup; dan (6) Auditor.

2. Peningkatan kualitas dan kuantitas pengelola di dalam dan di luar kawasan agro

Masalah yang dihadapi di desa Pemo termasuk di kawasan wisata agro adalah sumber daya manusia yang terbatas baik kualitas maupun kuantitasnya. Masalah yang menjadi kendala kurang berkembangnya wisata agro antara lain petani kurang mengerti tentang pupuk dan aplikasinya. Di sisi lain mereka kekurangan tenaga kerja yang produktif karena para petani sebagian besar berusia lanjut yakni 60 tahun ke atas. Selain itu, masalah hama kera dan babi hutan yang belum teratasi. Hal ini perlu kearifan lokal setempat untuk mengatasinya. Masalah pola tanam dan pengelolaan lahan yang terpencarpencar dan sendiri-sendiri seperti yang terdapat di desa Pemo dan di kawasan wisata agro perlu diubah menjadi pola tanam yang seragam dan kolektif untuk terhindar dari masalah hama. Pengetahuan tentang jenis tanaman lokal yang sudah beradaptasi, dan berorientasi agribisnis, pengetahuan mengakses berbagai teknologi dan informasikebutuhan dan harga pasar

3. Pengembangan keamanan lingkungan dari hama dan penyakittanaman

Sistem keamanan dapat dilakukan dengan membuat pagar pembatas yang mengelilingi kawasan agrowisata bila hal ini dimungkinkan. Pagar yang disarankan adalah pagar hidup yang memiliki nilai ekonomis bagi petani dan sebagai sumber makanan bagi satwa di kawasan wisata agro termasuk babi hutan dan kera. Perlu adanya petugas keamanan yang berpatroli mengelilingi kawasan baik berseragam maupun tidak. Selain itu, dibutuhkan pula petugas di pos-pos jaga yangselalusiaga dan melibatkan wargalokal.

4. Penyediaan dan pengadaan pupuk, bibit, pestisida. Sarana produksi pertanian yang penting untuk disediakan adalah pupuk, bibit, dan 
Fatima : Sikap dan perilaku petani desa Pemo sebagai desa wisata nasional

pestisida yang ramah lingkungan.Penerapan teknologi apapun dalam usaha pertanian sangat membutuhkan informasi dan multi media yang terkait dengan pengetahuan dan keterampilan petani dalam mengimplelementasikan di kawasan wisata agro.

5. Tersedianya pasar produk pertanian. Semangat dan gairah petani dapat meningkat dalam usaha wisata agro jika tersedia pasar yang pasti. Wawancara dengan beberapa petani di kawasan wisata agro bahwa kendalanya tidak adanya pasar memasarkan hasil pertanian dari kawasan wisata agro. Hasil penelitian menunjukkan $76 \%$ responden di KWA-8 menyatakan bahwa setuju dan lebih bersemangat bekerja jika tersedia pasar.

6. Tersedianya air. Di kawasan Agro pernah disediakan air oleh BTNK namun sering kali macet. Oleh karena itu perlu menyiapkan bak penampung air.

7. Tersediannya gudang (kebun petani, pasar) dan kendaraan pendingin. Tanamanpertanian sifatnya mudah rusak dan tidak tahan lama. Untuk mengatasi masalah tersebut perlu disiapkan gudang dan kendaraan pendingin yang dapat ditempatkan di kawasan wisata agro atau di tempat lain yang strategis.

8. Pelaksanaan sosialisasi pengembangan kawasan agro wisata. BTNKtelah melakukan sosialisasi bersama instansi terkait lainnya sejak tahun 2007 awal mula pencanangannya namun tidak dilakukan secara sistematis dan tidak kontinu serta tidak melibatkan semua masyarakat pemo. Untuk itu perlu sosialisasi kepada semua warga Pemo secara terstruktur atau sistematis.

9. Penyusunan program kerja secara bersama petani dan stakeholder.Program kerja yang telah disusun oleh BTNK telah melibatkan semua pihak namun dalam pelaksanaannya, rumusan tersebut tidak diawali dengan sosialisasi kepada petani pelaksana sehingga sering kali bantuan tersebut dimanfaatkan tidak di lahan pertanian wisata agro. Hal ini terjadi karena keterbatasan personil yang memberikan sosialisasi. Oleh karena itu pelibatan semua pihak perlu dilakukan terutama masyarakat desa pemo.

10. Sinkronisasi tugas dan tanggung jawab antara Dinas Pariwitasa dan Dinas lainnya serta BTNK yang bertanggung jawab dalam pengelolaan kawasan Kelimutu, dalam memfasilitasi kegiatan di desa Pemo. Perlu pemetaan yang jelas terutama wilayah yang menjadi tanggung jawab Dinas-Dinas yang terlibat. Telah ditegaskan oleh salah seorang ketua kelompok tani didesa Pemo bahwa adanya kebingungan warga, mau memilih program yang diprioritaskan.

\section{8) Menemukan kesiapan dan kesanggupan BTNK dalam menjalankan usaha wisata agro BTNK sejak tahun 2007 telah mewacanakan pengembangan wisata agro di kawasan kelimutu.}


Selanjutnya pada tahun 2008 disusunlah rencana detail kegiatan pengembangan kebun wisata yang bebasis lingkungan yang disebut dengan agro ecotourism Bufferzone untuk jangka waktu 2008 - 2010. Penyusunan rencana ini melibatkan beberapa pihak yakni PEMDA yang mencakup BAPPEDA, Dinas Perindustrian, BPMD Kabupaten Ende, Camat Kelimutu, Camat Detusoko, intens berusaha mengembangkan wisata agro di kawasan kelimutu. Inisiatif ini telah terbukti dengan terwujudnya wisata agro di KM 1- 9, walaupun hasilnya belum optimal. Sampai saat ini dari 8 (delapan) petani yang menggarap lahan di kawasan Agro-8 yang masih intens ada 3 orang.

Berdasarkan wawancara

dengan BTNK, dinyatakan bahwa pengembangan wisata agro pada awalnya bertujuan untuk pemberdayaan masyarakat desa Pemo agar dapat meningkatkan kesejahteraannya. Balai Taman Nasional Kelimutu hanya memfasilitasi untuk memberikan pelatihan, pemberian bibit, obatobatan, dan bantuan dalam bentuk lain sebagai stimulus awal dan diharapkan petani selanjutnya dapat mandiri. Berkaitan dengankeinginan petani yang telah dikemukakan, pihak BTNK tak menyanggupi karena keterbatasan dana dan sumber daya lain. Untuk itu konsep tersebut dapat diwujudkan jika semua pihak terlibat. Di sisi lain terdapat kendala, yakni lahan yang dijadikan sasaran pengembangan wisata agro kurang strategis tempatnya karena berada cukup jauh dari jalan raya. Juga lahan di pintu masuk area tersebut tidak diizinkan oleh pemiliknya untuk bisa dibuka jalan menuju lokasi. Hal ini menjadi pertimbangan yang rasional bagi BTNK untuk tidak melanjutkan pengembangan wisata agro di lokasi sekarang.

Oleh karenaitu, BTNK menyanggupi untuk memfasilitasi petani atau masyarakat desa Pemo yang memiliki lahan strategis dengan status kepemilikan yang jelas di luar area wisata agro yang telah dikembangkan selama ini, dan dijadikan lahan contoh.

\section{SIMPULAN}

Berdasarkan analisis data disimpulkan bahwa: (1) warga Pemo memiliki sikap dan perilaku setuju untuk mengembangkan agrowisata; (2) para petani kurang sanggup untuk melanjutkan pengembangan agrowisata karena kendala SDM; (3) Dampak yang telah diterima oleh petani adalah bermanfaat pada peningkatan SDM, ekonomi, dan finansial yang cukup baik; (4) Petani berkeinginan untuk terus difasilitasi dan membutuhkan pendampingan, bantuan sarana dan prasarana untuk kelancaran usaha agrowisata, dan (5) BTNK tidak sanggup untuk memenuhi keinginan para petani karena kendala biaya.

\section{UCAPAN TERIMA KASIH}

Terima kasih kepada pihak BTNK, para petani di kawasan agrowisata, serta semua pihak yang 
Fatima : Sikap dan perilaku petani desa Pemo sebagai desa wisata nasional

terlibat dalam penelitian ini, warga desa Pemo, Kepala Desa, dan para mosalaki.

\section{DAFTAR PUSTAKA}

Arikunto, S. 2010.Prosedur Penelitian Suatu Pendekatan Praktik. Jakarta:Rineka Cipta.

Azwar. 2012. Komunikasi Massa, Suatu Pengantar. Bandung : Simbiosa Rekatama Media.

Badan Pusat Statistik Kabupaten Ende. 2016. Kabupaten Ende Dalam Angka2016

Beureukat.2003. Faktor Lingkungan sebagai Penentu Perilaku Konsumen. Jurnal Ilmiah "Manajemen dan Bisnis". Volume 03 No.02

Oktober2003,11[Online].Tersedia: WWw.

manbisnis2.tripod.com/3_2_2.pdf.

[21 Oktober 2016].

Djarwanto.2010.

Pokok-

pokokAnalisaLaporanKeuangan,

EdisiKedua, CetakanPertama, Yogyakarta: BPFE.

Herianto. 2005. Komunikasi : Massa. Jakarta : Universitas Terbuka.

Mardikanto. 1993. Dasar-dasar Perilaku Individu. Surabaya : PT. Hanandu Gema Nusantara.

Mar'at. 1984. Suatu Konsep Komunikasi. Jakarta : PT. Raja Grafindo Persada
Mastronardi, L., Giaccio, V., Giannelli, A., \& Scardera, A.2015. Is agritourism eco-friendly? A comparison between agritourisms and other farms in italy using farm accountancy data network dataset. SpringerPlus, 4(1), 1-12. https://doi.org/10.1186/s40064015-1353-4

Mayasari, K., \& Ramdhan, T. 2013. Strategi Pengembangan Agrowisata Perkotaan. Buletin Pertanian Perkotaan, (3), 1.

Moleong, L. J. 2010. Metodologi penelitian kualitatif, Remaja Rosdakarya, Bandun

Nawawi, H.. 2011. Manajemen Sumber Daya Manusia untuk Bisnis yang Kompetitif, Gadjah Mada University Press, Yogyakarta

Palit, I. G., Talumingan, C., \& Rumagit, G. A. J. 2017. Strategi Pengembangan Kawasan Agrowisata Rurukan. Jurnal AgriSosioEkonomi Unsrat, 13(2), 2134

Sugiyono. 2010.Metodologi Penelitian Administrasi. Jakarta : CV. Alfabeta. Walgito. 2006. Komunikasi Dasar. UGM Press, Yogyakarta. 